\title{
ASSESSMENT OF THE EFFECT OF THE PRE-CAST BEAMS IG AXIAL SPACING ON THE EFFORT BRIDGE SPAN
}

doi: 10.2478/cqpi-2019-0038

Date of submission of the article to the Editor: 04/04/2019

Date of submission of the article to the Editor: 15/05/2019

Roman Gąćkowski ${ }^{1}$ - ocid id:0000-0002-4456-3011

Jacek Selejdak ${ }^{1}$ - ocid id: 0000-0001-9854-5962

${ }^{1}$ Czestochowa University of Technology, Poland

Abstract: In designing of reinforced concrete bridges are often used pre-cast of pre-tensioned or post-tensioned prestressed members. In professional practice, when designing bridge span pre-cast of pre-tensioned prestressed beams IG type, different axial beams spacing's are used and they are joined by a reinforced concrete slab. The paper presents a comparative analysis of an influence of the axial spacing of IG type beams in the cross-section of the bridge, on the bridge span effort, using standards PN-85/S-10042 and PN-EN 1992-2:2010. The optimal axial spacing of precast IG type beams is presented, while maintaining the standard conditions of ULS (Ultimate Limit State). Such a solution has a positive impact on the costs of the entire project, significantly lowering the global investment cost.

Keywords: bridge IG type beams, pre-cast bridge beams, pre-tensioned prestressed concrete beams.

\section{INTRODUCTION}

Prefabrication in the design of bridge structures is very popular due to the similar durability compared to monolithic technologies, the speed of construction of buildings, often excluding formwork and temporary supports, and a reduction in investment outlays. Prefabrication is always used where the short time of construction is important (spans over road obstacles are carried out within a few days) (Brózda, Selejdak, 2017).

The scope of using prefabricated bridge beams in the European Union depends on the country. According to (Machelski, 2006) in Germany, every fourth bridge object is designed on the basis of prefabricated beams and already in the Netherlands the use of prefabricated elements is almost $75 \%$.

An example of using prefabricated bridge spans for the first time is the Lake Pontchartrain Causeway bridge in the United States through the Pontchartrain lake near New Orleans in southern Louisiana (Fig. 1). It consists of two parallel bands of road spaced about 24 meters apart. Each road band has two road lanes. The northern part of the bridge measures $39.92 \mathrm{~km}$ and was put into use in 1956 and the southern part $38.17 \mathrm{~km}$ long, was commissioned in 1969. 


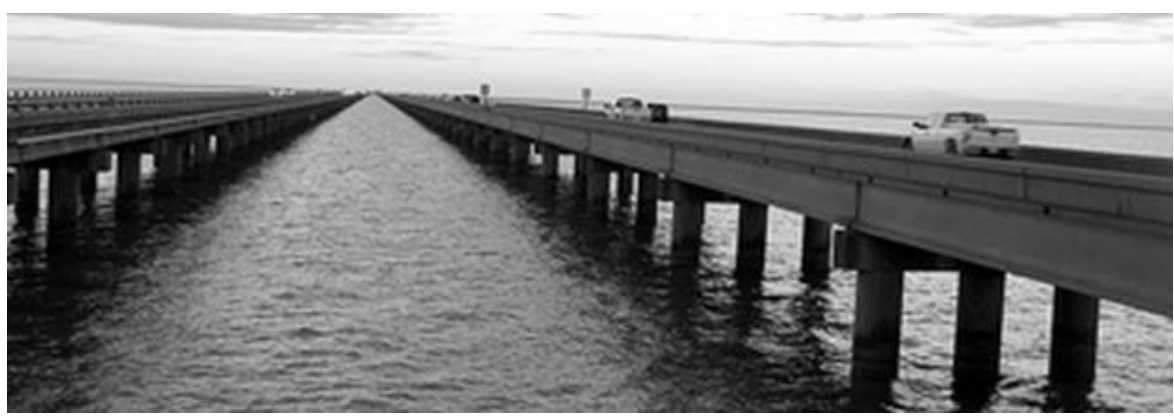

Fig. 1: View of the prefabricated Lake Pontchartrain Causeway bridge in the United States (http://mapio.net/s/13360936/)

In Poland, the use of prefabricated elements on a large scale dates from the second half of the twentieth century. The prefabrication plants have developed about 20 types of prestressed bridge beams. An example of using prefabricated elements in bridge structures is the IG beam, which can be used in various construction systems and static schemes. The standard lengths of prefabricated IG beams in (Katalog...ERGON, 2009) are:

- IG600

$9.0 \mathrm{~m} ; 12.0 \mathrm{~m} ; 15.0 \mathrm{~m}$

- IG1400 $20.0 \mathrm{~m} ; 22.0 \mathrm{~m} ; 24.0 \mathrm{~m} 26.0 \mathrm{~m}$;

- IG1800 $28.0 \mathrm{~m} ; 32.0 \mathrm{~m} ; 36.0 \mathrm{~m} ; 42.0 \mathrm{~m}$;

IG beams are joined at the construction site with reinforced concrete monolithic slab. The height of the beams adopted depending on the span between $60 \div 180 \mathrm{~cm}$. Key parameters of the IG beams are shown in Table 1.

Table 1

Parameters of pre-cast bridge beams IG acc. to

\begin{tabular}{|c|c|c|c|c|c|c|c|}
\hline $\begin{array}{c}\text { Type } \\
\text { of } \\
\text { beam }\end{array}$ & $\begin{array}{c}\text { Effective } \\
\text { length } \\
\text { Leff }\end{array}$ & $\begin{array}{c}\text { Actual } \\
\text { length } \\
L_{b}\end{array}$ & $\begin{array}{c}\text { Number } \\
\text { of } \\
\text { tendon } \\
s\end{array}$ & $\begin{array}{c}\text { Volume } \\
\text { of a } \\
\text { beam }\end{array}$ & $\begin{array}{c}\text { Mass } \\
\text { of } a \\
\text { beam }\end{array}$ & $\begin{array}{c}\text { Maximal } \\
\text { spacing } \\
\text { of a } \\
\text { girder } \\
\text { a }\end{array}$ & $\begin{array}{c}\text { Calculated } \\
\text { maximal } \\
\text { vertical } \\
\text { reaction on } \\
\text { the bearing } \\
V_{\max }\end{array}$ \\
\hline & [m] & [m] & [pcs.] & {$\left[\mathrm{m}^{3}\right]$} & {$[\mathrm{t}]$} & [m] & {$[\mathrm{kN}]$} \\
\hline IG600 & 9.0 & 9.6 & 16 & 3.0 & 8.0 & 2.2 & 844 \\
\hline IG600 & 12.0 & 12.6 & 22 & 3.6 & 9.8 & 1.8 & 770 \\
\hline IG600 & 15.0 & 15.6 & 26 & 4.3 & 11.5 & 1.4 & 665 \\
\hline $1 \mathrm{G} 600$ & 18.0 & 18.6 & 29 & 5.0 & 13.3 & 1.0 & 538 \\
\hline IG1400 & 20.0 & 20.6 & 32 & 9.9 & 26.6 & 2.4 & 1449 \\
\hline IG1400 & 22.0 & 22.6 & 35 & 10.5 & 28.5 & 2.2 & 1392 \\
\hline IG1400 & 24.0 & 24.6 & 38 & 11.2 & 30.3 & 2.0 & 1329 \\
\hline IG1400 & 26.0 & 26.6 & 40 & 11.9 & 32.2 & 1.8 & 1258 \\
\hline IG1800 & 28.0 & 28.8 & 47 & 23.4 & 63.2 & 2.5 & 1961 \\
\hline IG1800 & 32.0 & 32.8 & 56 & 26.0 & 70.2 & 2.2 & 1910 \\
\hline IG1800 & 36.0 & 36.8 & 60 & 28.6 & 77.3 & 1.8 & 1748 \\
\hline IG1800 & 42.0 & 42.8 & 65 & 32.6 & 88.0 & 1.4 & 1606 \\
\hline
\end{tabular}

Source: (Katalog...ERGON, 2009) 


\section{GEOMETRIC DATA AND COMPRESSION PARAMETERS OF THE ROAD VIADUCT}

The analysis of the bearing capacity of a bridge span, made of prefabricated IG1800 pre-stressed concrete beams, was carried out on the example of a road viaduct (Fig. 2 ). Different variants of the axial spacing of IG beams in cross-section were taken (Fig. 3). The variant V-01 was taken as the basis (Fig. 2).
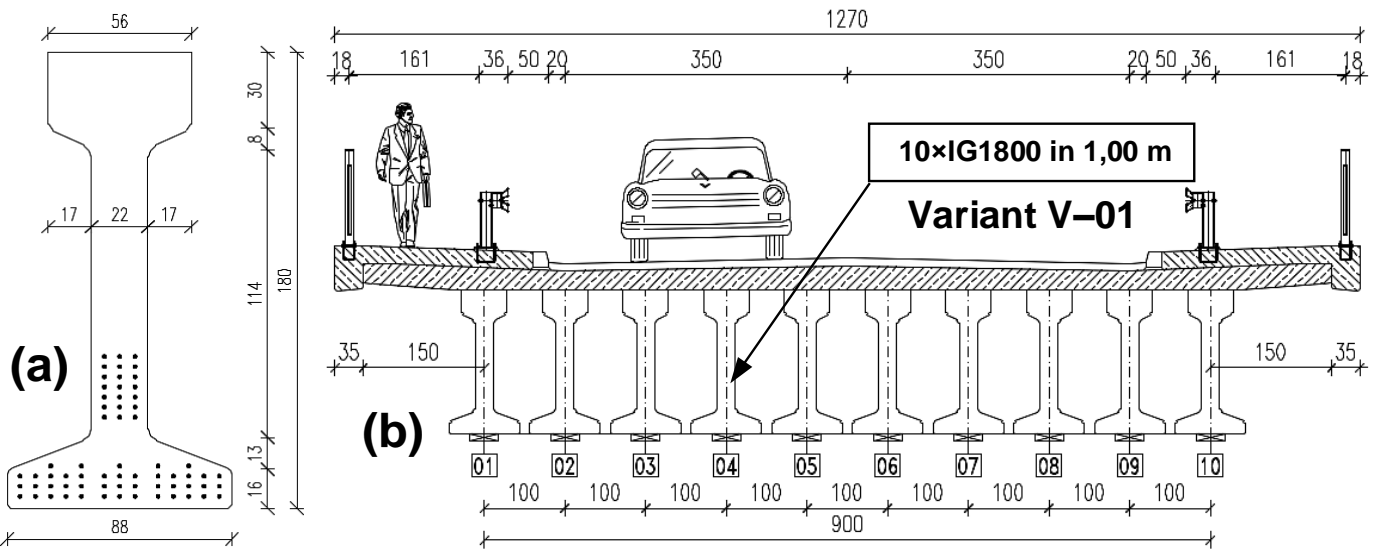

Fig. 2. The cross section of the road viaduct: (a) The dimensions of the beam IG1800;

(b) V-01 - the base $10 \mathrm{IG}$ beams at a spacing of $1.0 \mathrm{~m}$;
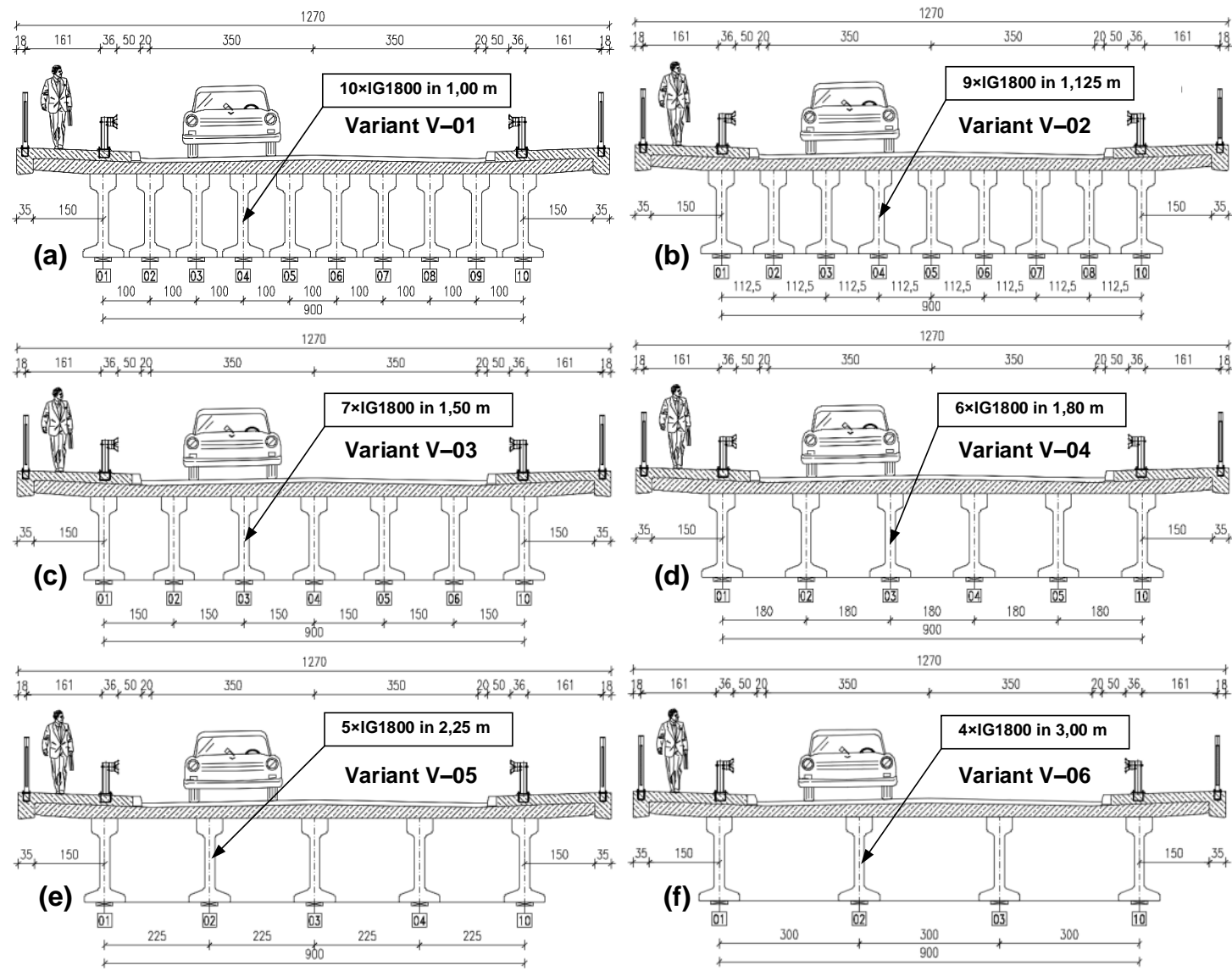

Fig. 3. Variants of cross-sections of a road viaduct:

(a) V-01 variant with 10 beams IG1800; (b) V-02 variant with 9 beams IG1800;

(c) V-03 variant with 7 beams IG1800; (d) V-04 variant with 6 beams IG1800;

(e) V-05 variant with 5 beams IG1800; (f) V-06 variant with 4 beams IG1800. 
They adopted the basic parameters of the road viaduct in static calculations and strength:

- Effective span in the support axes: $\mathrm{L}_{\text {eff }}=42.0 \mathrm{~m}$

- Overall length of the IG1800 beam: $L_{b}=42.80 \mathrm{~m}$

- Total width of the viaduct:: $b_{\text {tot }}=13.0 \mathrm{~m}$

- Static diagram: single-span structure

- Road load class: according to $\mathrm{PN}-85 / \mathrm{S}-10030$ class $A+$ load on a special vehicle of class 150 according to PN-EN 1991-2: 2007..... Standard model LM1 + Standard model LM3 The presented bridge object is a typical single-span road viaduct over a water obstacle (Blikharskyy Z., et al. 2017). Detailed static and strength analysis of the bridge span was based on two standards:

- PN-91/S-10042 Bridge structures. Concrete, reinforced concrete and prestressed structures. Design (bridge standard).

- PN-EN 1992-2:2010. Eurocode 2. Design of concrete structures. Part 2. Concrete bridges - Design and detailing rules.

Static calculations were made on the Frame 3D model and Shell model in Autodesk Robot Structural Analysis Professional 2018. In this model uses beam elements (IG1800 beams, prestressed concrete and reinforced concrete support cross-members) and shell elements (reinforced concrete slab joining with prefabricated beams of the road viaduct). The diagram of the calculation model for variant $\mathrm{V}-01$ is shown in (Fig. 4).
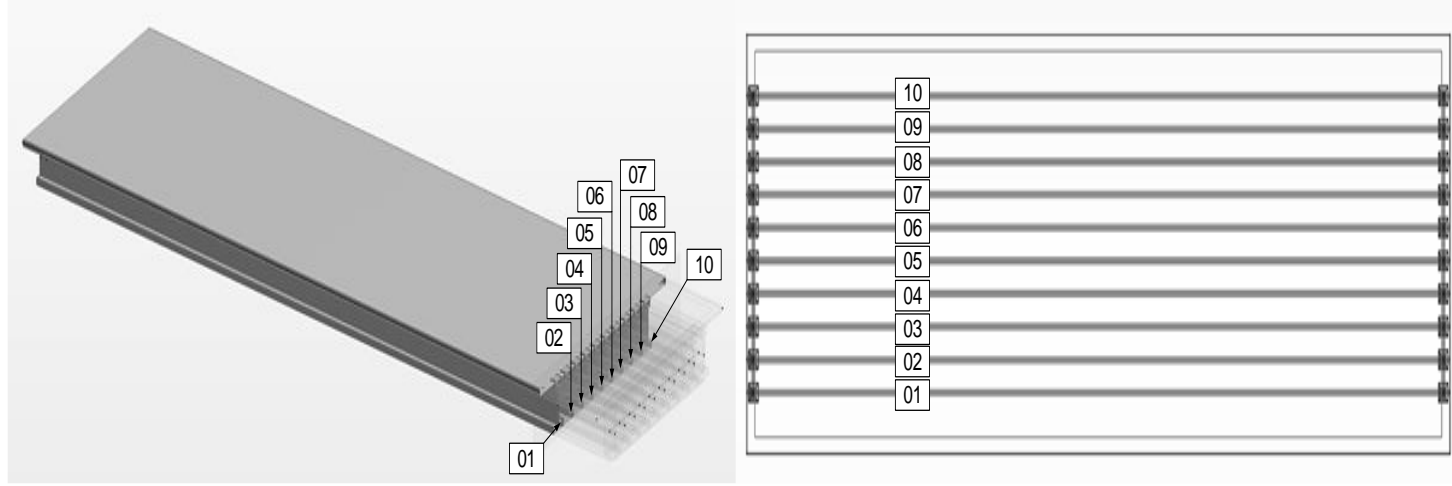

Fig. 4. The calculation model of the road viaduct - basic variant V-01

In the capacity analysis of a bridge span, were used the results of static and strength calculations for the basic variant $\mathrm{V}-01$ and optional variants from $\mathrm{V}-02$ to $\mathrm{V}-06$. IG1800 beams have a height of $1.80 \mathrm{~m}$, width of the top shelf $0.56 \mathrm{~m}$ and width of the web 0.22 and width of the bottom shelf $0.88 \mathrm{~m}$. (Fig. 3). The total length of the IG1800 beam is $42.8 \mathrm{~m}$. and is made of B60 concrete in (PN-91/S-10042) (C50/60 in PN-EN 1992-2:2010). The prestressing reinforcement is 65 tendons made of steel $\mathrm{Y} 1860 \mathrm{~S} 7$ (65 tendons in the tensile zone of concrete). Concrete reinforcement accepted steel A-IIIN according to PN-91/S-10042.

IG1800 prefabricated beams were joined with a reinforced concrete platform slab with a minimum thickness of $0.27 \mathrm{~m}$. The face of IG1800 beams joined monolithically using support transom, which were based on bearings in the spacings the same as main beams (Fig. 3). 


\section{ANALYSIS OF THE LOAD CAPACITY OF A ROAD VIADUCT}

Static calculations were performed in Autodesk Robot Structural Analysis Professional 2018 while strength calculations were made in accordance with PN-91/S-10042 and PN-EN 1992-2: 2010. The combination of loads was made on the basis of (Gąćkowski, 2013; PN-EN 1990:2004; PN-EN 1991-2:2007). Static calculations include the following loads from: dead load structures, green and hardened concrete of the bridge slab, the weight of the bridge equipment, shrinkage of concrete, loads of live (load a crowd of pedestrians and load of vehicles). The loads of live according to the standards PN-91/S-10042 and PN-EN 1992-2:2010, it's very different from each other. According to standard PN-91/S-10042 the viaduct is designed for class $A$ (uniformly distributed load $q+$ load of vehicle $\mathrm{K}$ or load of car $\mathrm{S}+$ load a crowd of pedestrians $\mathrm{q}_{\mathrm{t}}$ ).

According to standard PN-EN 1992-2:2010 the loads of live is presented as the models (PN-EN 1991-2:2007): LM1 (concentrated and uniformly distributed loads, which cover most of the effects of the traffic of lorries and cars), LM2 (a single axle load applied on specific tyre contact areas which covers the dynamic effects of the normal traffic on short structural members) and LM4 (a crowd loading, intended only for general verifications). In static calculations were also included the special loads in a wheeled vehicle of class 150 according to STANAG 2021.

First calculations were made for variant V-01, in which the axial distance of prefabricated beams is $100 \mathrm{~cm}$ (catalog distance of axial). In the next steps calculations were made for variants from V-02 to V-06. All beams in each variants were analyzed and the most reliable results were selected on this basis. Beams 01 and 10 (external beams) in each variant are in the same place of the cross-section. The internal beams from 02 to 09 of the road viaduct marked changed (Fig. 4). The axial spacing of the middle beams of the viaduct was $1,00 \mathrm{~m}$ for variant $\mathrm{V}-01 ; 1.125 \mathrm{~m}$ for variant $\mathrm{V}-02 ; 1.50 \mathrm{~m}$ for variant $\mathrm{V}-03 ; 1.80 \mathrm{~m}$ for variant $\mathrm{V}-04 ; 2.25 \mathrm{~m}$ for variant $\mathrm{V}$ 05 and $3.00 \mathrm{~m}$ for variant $\mathrm{V}-06$. The connecting element was a reinforced bridging slab with a minimum thickness of $0.27 \mathrm{~m}$.

According to standard PN-91/S-10042 this type of bridge structure can be analyzed in the scope of extra-elastic bearing capacity. Loads combinations in static analysis were adopted in 4 load stages:

- initial stage with a non-associated slab of bridge,

- transient stage (assembly) with a non-attached slab of bridge,

- implementation stage the slab integral with the beams,

- operation stage the slab integral with the beams.

According to the standard PN-91/S-10042 point 9.4. composite reinforced concrete structures should be checked due to the load-bearing capacity, understood as the value of internal forces, which induce in the prestressed element the destruction of the cross-section due to:

- exhaustion resistance of the tensile zone when bending

$$
\mathbf{M}_{\mathrm{ns}}=\mathbf{c} \cdot \mathbf{R}_{\mathrm{pk}} \cdot\left(\mathbf{S}_{\mathrm{p}}+\mathbf{S}_{\mathrm{pc}}\right)+\mathbf{R}_{\mathrm{ak}} \cdot\left(\mathbf{S}_{\mathrm{a}}+\mathbf{S}_{\mathrm{ac}}\right) \geq \mathbf{S}_{\mathbf{2}} \cdot \mathbf{M}_{\mathrm{k}}
$$

- exhaustion resistance of the concrete compression zone

$$
\mathbf{M}_{\mathrm{nb}}=\mathbf{R}_{\mathrm{bk}} \cdot \mathbf{S}_{\mathrm{bc}}+\mathbf{R}_{\mathrm{ak}} \cdot\left(\mathbf{S}_{\mathrm{a}}-\mathbf{S}_{\mathrm{ac}}\right)+\boldsymbol{\sigma}_{\mathrm{pc}} \cdot \mathbf{S}_{\mathrm{pc}} \geq \mathbf{S}_{\mathbf{3}} \cdot \mathbf{M}_{\mathrm{k}}
$$

In addition, check the condition (3) related to the drawing moment and tensile stress in the concrete according to $\mathrm{PN}-91 / \mathrm{S}-10042$ point. 9.3.3. 
- tensile stress in the concrete

$$
\mathrm{M}_{\mathrm{cr}}=\mathrm{M}_{\mathrm{gc}}+\mathrm{M}_{\mathrm{gn}}+\left[\left(\sigma_{\mathrm{dc}}^{\mathrm{p}}-\Delta \sigma_{\mathrm{dc}}\right)+\lambda \cdot \mathrm{f}_{\mathrm{ctm}}\right] \cdot \mathrm{W} \geq \mathrm{s}_{1} \cdot \mathrm{M}_{\mathrm{k}}
$$

According to PN-EN 1992-2:2010, the considered bridge structures can be analyzed in terms of elastic bearing capacity. In contrast to standard PN-91/S-10042 calculations were made for situations: persistent, transient and accidental. According to the standard PN-EN 1992-2:2010 the resistance limits of a prestressed composite structure and reinforced concrete structure should be checked using the dependence:

$$
\mathbf{M}_{\mathrm{Ed}} \leq \mathbf{M}_{\mathrm{Rd}}=\mathbf{M}_{\mathbf{d}}+\mathbf{M}_{\mathrm{nd}}
$$

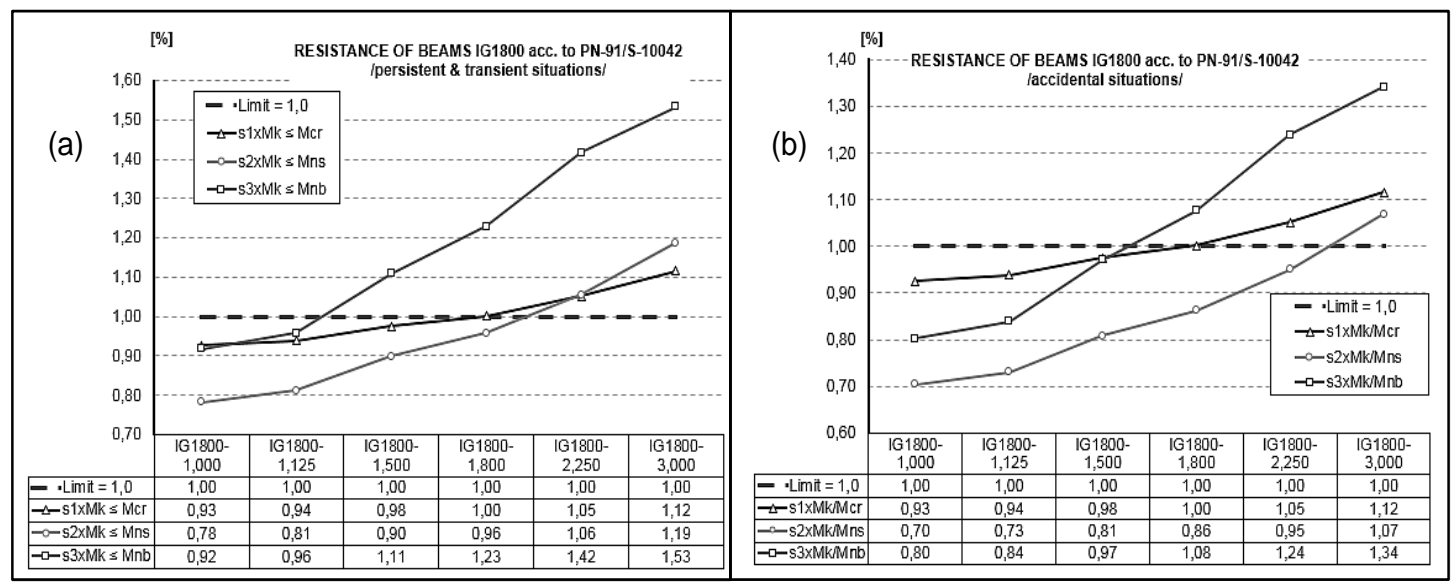

Fig. 5. Diagrams of resistance bridges span according to PN-91/S-10042 by using calculations: (a) for the basic system, where the safety coefficient are respectively $\mathrm{s}_{1}=1.2 ; \mathrm{s}_{2}=2.0$ and $\mathrm{s}_{3}=2.4 ;$ (b) for an accidental system, where the security coefficients are respectively $\mathrm{s}_{1}=1.2 ; \mathrm{s}_{2}=1.8$ and $\mathrm{s}_{3}=2.1$

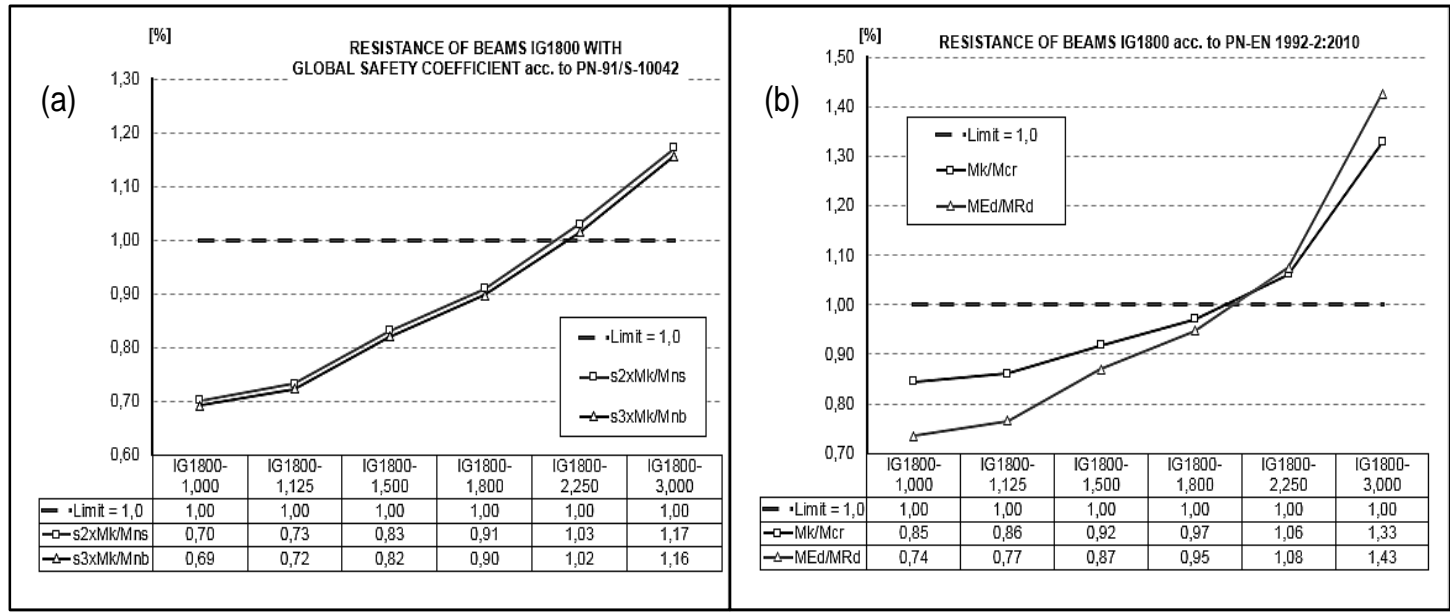

Fig. 6. Diagrams of resistance for the bridge span: according to the standard PN-91/S-10042 with the change of the global safety coefficient system for condition (1) where $\mathrm{s}_{2}=1.53$ according to PN-91/S-10042 and condition (2) where $\mathrm{s}_{3}=1.81$ according to PN-91/S-10042. (b) according to the standard PN-EN 1992-2:2010 and condition (4), without safety coefficient in the standard (Machelski, 2006)

The analysis of the bridges span capacity was carried out based on standards (Kuś, Plewako, 2004; PN-EN 1992-2:2010) and study PN-91/S-10042 related to changes in the design and calculation of prestressed structures in particular, changes in global safety coefficient to partial safety coefficient. 
Fig. 5(a) is shown in the diagrams of resistance for the basic system (persistent \& transient situations):

- equation (3) associated with the drawing moment $M_{c r} \geq s_{1} \cdot M_{k}$,

- equation (1) associated with the limit resistance due to the exhaustion of the tensile strength of the moment $M_{n s} \geq s_{2} \cdot M_{k}$,

- equation (2) associated with the ultimate load capacity due to the exhaustion of compressive strength $M_{n b} \geq s_{3} \cdot M_{k}$.

It should be noted, that for variants V-01 (spacing IG1800 what $1.0 \mathrm{~m}$ ) and V-02 (spacing IG1800 what $1.125 \mathrm{~m}$ ), all resistance conditions are met respectively in the range from $78 \%$ to $93 \%$ and from $81 \%$ to $96 \%$. In the other variants from V-03 to V06 , the spacing of beams over $1.50 \mathrm{~m}$ are exceeded by a maximum of $53 \%$ for a spacing of beams $3,00 \mathrm{~m}$.

Fig. 5(b) shows the same graphs as in Fig. 5(a) but for the unique system. The difference is only due to the use of other safety coefficient in accordance with the standard (PN-91/S-10042). In this case, for variants V-01 (beam spacing at $1.0 \mathrm{~m}$ ), V02 (beam spacing at $1.125 \mathrm{~m}$ ) and V-03 (beam spacing at $1.50 \mathrm{~m}$ ), all resistance conditions are met respectively in the range from $70 \%$ to $98 \%$. Above a spacing of $1.5 \mathrm{~m}$, resistance conditions for IG1800 beams are exceeded by a maximum of $34 \%$.

Fig. 6(a) shows two diagrams for conditions (1) and (2) of limit bearing capacity according to the standards (PN-91/S-10042). In this case, the global safety coefficient was applied in accordance with acc. to (Kuś, Plewako, 2004). For the condition (1) associated with tensile bearing capacity, the value of the safety coefficient $S_{2}=1.52$, due to exhaustion of tensile bending strength $M_{n s} \geq s_{2} \cdot M_{k}$ and the value of the safety coefficient $s_{3}=1.8$, due to exhaustion of concrete compressive strength $M_{n b} \geq s_{3} \cdot M_{k}$ In this case, according to PN-91/S-10042 and on the basis (Kuś, Plewako, 2004) using the formulas (1), (2), it can be noticed that the spacing of beams up to $1.80 \mathrm{~m}$ for variants V-01, V-02, V-03 and V-04 all resistance conditions are met in the range from $69 \%$ to $91 \%$. For a spacing of more than $1.80 \mathrm{~m}$, the bearing capacity of the beams is exceeded by a maximum of $17 \%$.

Fig. 6(b) shows the diagrams of resistance for condition (4) in accordance with the recommendations of standard PN-EN 1992-2: 2010. In this case, the limit load capacity varies significantly depending on the spacing of pre-cast beams and depends on the width of the reinforced concrete platform slab with the prefabricated IG1800 pre-stressed beam. It should be noted, that in the catalog spacing of beams $\mathrm{V}-01$ equals $1.0 \mathrm{~m}$, the condition of resistance is met in $85 \%$. For a spacing of beams such as $1.125 \mathrm{~m}$ for variant $\mathrm{V}-02,1.50 \mathrm{~m}$ for $\mathrm{V}-03$ and $1.80 \mathrm{~m}$ for $\mathrm{V}-04$, the stresses are used respectively maximum in $86 \%, 92 \%$ and $97 \%$. For spacing of beams $2.25 \mathrm{~m}$ for variant V-05 and $3.00 \mathrm{~m}$ for V-06 the bearing capacity of the beams is exceeded by a maximum of $43 \%$.

\section{CONCLUSIONS}

The article presents several ways of checking the load-bearing capacity of a composite bridge span of prefabricated IG1800 prestressed concrete beams and a reinforced concrete platform slab. The presented analysis of the span's bearing capacity was dependent on the spacing of prefabricated beams. It has been shown that in some cases, the distance between prefabricated beams can be bigger than the 
recommended catalog value. It is crucial to decide which standards will be used during calculation of the structure.

The standard PN-91/S-10042 applied to the calculation states that the maximum spacing of beams is $1.5 \mathrm{~m}$, which corresponds to the variant V-03 and consequently to 7 beams. In the classical (catalog) variant, there are 10 IG1800 beams in the crosssection of the viaduct.

On the other hand by introducing changes to the global safety coefficient in accordance with (Kuś, Plewako, 2004), the maximum distance is $1.80 \mathrm{~m}$, which corresponds to the V-04 variant and consequently to 6 IG1800 beams. Moreover, the Eurocode standards also states that the optimal spacing of IG1800 beams in the cross-section is $1.80 \mathrm{~m}$ for variant V-04. In summary, it is desirable to use $1.50 \mathrm{~m}$ spacing beams IG1800.

Therefore, the reduced number of beams in cross-section gives financial savings in a construction and executive design of bridge without sacrificing the safety of structure.

\section{REFERENCES}

Blikharskyy, Z., Shnal, T., Khmil, R., 2017. The influence of the damaged reinforcing bars on the stress-strain state of the rein-forced concrete beams. Production Engineering Archives, 14, 23-26, DOI: 10.30657/pea.2017.14.06

Brózda, K., Selejdak, J., 2017. Stay-in-Place Formworks Applied in Civil - Engineering Requirements and Scope of the Control. $10^{\text {th }}$ Conference on Terotechnology Location: Kielce Trade Fair Ctr, Kielce, POLAND, Book Series: Materials Research Proceedings, ed. by: Szczotok A; Pietraszek J; Radek N., 5, 96-100, DOI: 10.21741/9781945291814-17.

Gąćkowski, R., 2013. Tablice i algorytmy do wymiarowania zginanych elementów żelbetowych, Verlag Dashöfer, Warszawa.

http://mapio.net/s/13360936/ available on-line 20.04.2019

Katalog belek mostowych typu ERGON, 2009. Ergon Poland, Mszczonów.

Kuś, S., Plewako, Z., 2004. Wymagania dotyczące projektowania konstrukcji sprężonych. Praca naukowa finansowana ze środków KBK w latach 2002/2004 jako projekt badawczy. Komentarz naukowy do PN-B-03264:2002 Konstrukcje betonowe, żelbetowe i sprężone" Część podstawowa, Instytut Techniki Budowlanej, Warszawa.

Machelski, C., 2006. Obliczenia mostów z betonowych belek prefabrykowanych, Wydawnictwo DWG, Wrocław.

PN-85/S-10030. Obiekty mostowe. Obciążenia.

PN-91/S-10042. Bridge structures. Concrete, reinforced concrete and prestressed structures. Design (bridge standard).

PN-EN 1990:2004. Eurokod: Podstawy projektowania konstrukcji.

PN-EN 1991-2:2007. Eurokod 1: Oddziaływanie na konstrukcje. Część 2: Obciążenia ruchome mostów.

PN-EN 1992-2:2010. Eurocode 2. Design of concrete structures. Part 2. Concrete bridges - Design and detailing rules 